\title{
Translation of Colloquialisms in the Arabic-into-English Subtitled Film, The Dupes
}

\author{
Aladdin Al-Kharabsheh (Corresponding author) \\ The Hashemite University, Jordan \\ Omar Yassin \\ The Hashemite University, Jordan
}

Received: 18-04-2017

doi:10.7575/aiac.ijclts.v.5n.3p.18
Accepted: 04-06-2017

Published: 31-07-2017

\begin{abstract}
This study attempts to investigate the difficulties and problems that subtitlers may encounter in subtitling colloquial expressions from Arabic into English. To achieve the main objectives of the study, some authentic examples have been obtained from the subtitled film The Dupes and analyzed linguistically and translationally in order to identify the subtitling inaccuracies, to highlight the subtitling strategies used by the film's subtitler, and to draw other workable subtitling solutions for dealing with colloquialisms or slang language. Analysis isolates three major problems relevant to subtitling Arabic colloquial expressions into English: (1) some colloquialisms, especially those reflecting religious overtones, have been missubtitled, (2) some colloquialisms have been totally dropped out from subtitling (i.e. zerosubtitling), (3) and in subtitling certain colloquialisms, a considerable subtitling loss has occurred. Finally, to resolve such recalcitrant problems and difficulties, the study, in its concluding part, suggests some other practical subtitling mechanisms, other than the ones that have been adopted by the film's subtitler.
\end{abstract}

Keywords: Screen Translation, Subtitling, Colloquialisms, Communicative Translation, Idiomatic Translation, Literal Translation

\section{Introduction}

Screen translation, audiovisual translation, or multimedia translation is an expanding and vibrant sub-discipline within Translation Studies, as since its birth in the twentieth century, it has been gravitating unprecedented interest, and experiencing a remarkable degree of activity at all levels (Chiaro, Heiss, \& Bucaria, 2008; Díaz-Cintas 2003; Jorge Díaz-Cintas \& Anderman, 2008; Jorge Díaz-Cintas \& Remael, 2014; Orero, 2004). To this effect, Jorge Díaz-Cintas stresses that "audiovisual translation is a field that has been growing in significance and visibility in recent decades, and many young, enterprising scholars are directing their interests and efforts to the analysis of audiovisual programmes" (2008, p. 5).

The spectacular development of screen translation is traceable in the changes in the terminology that scholars have used to designate this field of inquiry at different stages. Given the fact that screen translation has significantly contributed to the development of cinema, particularly, film, the terms film translation and film dubbing gained so much currency in early scholarly work(e.g. Delabastita, 1989; Fodor, 1976; Snell-Hornby, 1988/1995).Later on, the term audiovisual translation has been coined to embrace television and video material, whereas the term multimedia translation has been chiseled outto cover all sorts of media, communication and technology(e.g. Chiaro, 2009; Jorge Díaz-Cintas \& Remael, 2014; Gambier \& Gottlieb, 2001; Pérez-González, 2014; Varela, 2002).Though the term audiovisual translation (AVT) has been gaining ground in recent years, and is predominantly used in this particular strand of Translation Studies, choice, in this paper, has rested with the coinage screen translation ( e.g. Condinho Bravo, 2008; Mason, 1989; O'connell, 2007), for it is seen a blanket term that can cover all these products displayed on the screen (e.g. films, audiovisual material, and multimedia material). Screen translation should be seen as the technicalities and modalities used to enable the linguistic transfer of an audiovisual or multimedial text from one language to another to take place(for a similar account, see also Chaume 2004, p. 31, cited in Cabrera \& Bartolomé, 2005).Indeed, screen translation takes different forms such as subtitling, dubbing, voice-over, narration, interpreting, surtitling; yet, their main skopos remains invariant: to enable audiovisual and multimedia programmes to be transferred across linguistic borders (cf. Chang, 2012; Gottlieb, 2008).

Since this investigation deals with a subtitled film, it is useful to shed light on subtitling. Subtitling can be viewed as a kind of written translation that transfers and clarifies a spoken language for people watching a videotaped material. Luyken and Herbst define subtitles as "condensed written translations of original dialogue which appear as lines of text, usually positioned towards the foot of the screen" (1991, p. 31). For Ivarsson and Carroll the term subtitle designates a "text, drawn or printed on paper or cardboard, filmed and inserted between sequences of the film" (1998, p. 9), wheras d'Ydewalle looks at subtitles as "a translation of the voices heard on the soundtrack" (2002, p. 59). Indeed, "subtitles appear and disappear to coincide in time with the corresponding portion of the original dialogue and are almost always 
added to the screen image at a later date as a post-production activity" (Jorge Díaz-Cintas \& Anderman, 2008 , p. 36).Thus, subtitles can not only be viewed as "snippets of written text superimposed on visual footage that convey a target language version of the source speech" (Pérez-González, 2014, pp. 15-16), but also as "diasemiotic" or "intermodal" form of screen translation (Gottlieb, 1997, p. 95), since a shift from the spoken to the written mode takes place (see also Romero-Fresco, 2011).

The driving force for carrying out this study is the fact that most translation studies concentrate on translating colloquialisms within the context of the mainstream Translation Studies, but this one will try to shift the focus to the audio-video channel of communication, or rather to the impoverished but fertile area of concentration, the ArabicEnglish Screen Translation Studies. Indeed, the central concern of this paper will be with colloquialisms or slang language, as one of the most problematic areas that translators may face in subtitled films, especially in the language pair, English and Arabic (see also Thawabteh, 2011). Colloquialism is a variety of language commonly employed in conversation or other styles of communication in informal situations. Within this context, Fawcett stresses that "a constant headache in all forms of translation is posed by phraseology marked as familiar or slang" (2003, p. 157), while Al-Azzam and Al-Kharabsheh assert that colloquialism can be "a factor which further complicates the abridgement process" (2011, p. 557).

The study's main objective is threefold: to explore the translation difficulties and problems associated with the subtitled film, The Dupes, to identify the translation strategies that the film's subtitler used in rendering these colloquialisms, and to put forth some practical and pragmatic translation solutions, techniques and/or strategies for dealing with these colloquialisms in the Arabic-English directionality of subtitling. This film (i.e. The Dupes) is a Syrian drama that was produced in 1972 based on Ghassan Kanafani's 1963 novel, 'Men in the Sun'. This novel was converted into a film that was directed by Tawfeeq Saleh under the title 'The Dupes', and the film was subtitled into English. The film is about three Palestinian refugees, after the 1948 Nakba (i.e. the 1948 Catastrophy), who take an adventurous journey from Palestine to Kuwait as to work there and improve their lives. This journey is shrouded with many risks and the three men end up expiring under the Deseret's hot sun. The film gives an inspiration for the Arabs to speak up and reject being treated as dupes!

Since English and Arabic are spoken by nations that are geographically, religiously and socially distinct, the translation difficulties and problems relevant to the subtitled film, the Dupes, can often be linked to the sharp cultural differences between these two languages, i.e., Arabic and English. In this vein, Al-Azzam and Al-Kharabsheh confirm that "this difference in social view, which gives rise to many translation problems, results from the two varying cultures and settings and cannot be bridged without giving the receptive language reader enough awareness about the values and norms of the source language" (2011, p. 569). Therefore, translating colloquial expressions figuring in a subtitled work from Arabic into English like the Dupes is not only dependent on a good understanding of the film in question, but it also requires knowing the exact context of situation in which any given colloquial expression is used and its intended pragmatic meaning in the SL. The translator's competence and expertise are also believed to play a pivotal role in handling these informal phraseology and in maintaining quality in subtitling (for more details on quality in subtitling, please see Taivalkoski-Shilov, 2008).

\section{Methodology}

This is an evaluative-descriptive study that is concerned with an analytical examination of the difficulties and problems associated with translating Arabic colloquialisms into English in the subtitled film, The Dupes. Thus, data for this study has been obtained from one source: The Dupes film. The film being acted in colloquial Arabic is a rich source for the kind of data needed for this study. The current study will attempt to analyze the obtained data (i.e. the obtained colloquialisms) from a socio-linguistic point of view, and then, more importantly, from a translational perspective, i.e., the collected data will be analyzed linguistically then translationally. This will be done through comparing and contrasting the selected subtitles (i.e. the screen translation) with the intended meaning of their corresponding SL colloquialisms, based on their immediate context and the broader context of the film.

In other terms, the obtained data will be analyzed in light of their contextual interpretation, i.e., a special focus will be placed on the context of situation. The analysis will also give a special attention to the cultural aspect by falling on a backdrop as the Arab Palestinian culture, the language of the selected film. Accordingly, data analysis will take the following order in this study: first, the discussion will present the film scene that contains the colloquialism(s) in Arabic, then, it will be followed by its English subtitling, and finally a discussion will follow out. For an easy perusal of the problem of the study, the colloquialism in question will be underlined in the body of this study as well as its subtitling.Lastly, towards the end of every discussed example, a more adequate subtitling will be suggested.

\section{Theoretical Framework: Colloquialisms in Screen Translation}

Popowich et al. (1997)conduct a study where they confirm that Colloquial English (CE) as found in television programs or typical conversations is different from texts found in technical manuals, newspapers and books. The study looks at some of the theoretical and implementational issues involved in translating CE. It also presents a fully automatic largescale multilingual natural language processing system for the translation of CE input text, as found in the commercially transmitted closed-caption television signal, into simple target sentences. The approach is based on the Whitelock Shake and Bake's machine translation paradigm, which relies heavily on lexical resources. (Hamaida, 2007) examines the feasibility of translating spoken slang or dialect into subtitles. As the use of slang and/or dialect is associated with spoken rather than written language, the challenge of subtitling dialog spoken in slang and dialect highlights intriguing 
issues related to the distinction between spoken and written language, and to the subtitler's perception of the function of the subtitle.

Eftekhari (2008) provides an overview on translating colloquialism in Iranian films with English subtitles. Based on Viney and Darbelnet's translation procedures, the study takes an Iranian film entitled The Wind Will Carry Us by 'Abbas Kiarostami', as the subject in order to see how the translator deals with colloquial expressions in its source text, supported with a comparison between the SL version and the TL version. Taking faithfulness, naturalness, expected effects and fluency as judging criteria for comparing the two versions, the study finds out that the most frequently applied procedure is adaptation, changing for functional equivalence, and even recreation in place of faithful translation. Finally, the study concludes that adaptation and localization of the film subtitles make the colloquial expressions in the film different and sometimes they lose the original color. In order to evoke the intended effect on the target language audience with the subtitles and in order to let them recover the scenes, the translator must provide the more local information in preference to the more global.

Pedersen (2009)carries out a study that focuses on the slang of British English. This study has been possible through an analysis of a contemporary film and a TV-show in order to see how common the use of slang is in these kinds of medias. The intention is also too see if slang differs according to gender, and in what different areas slang is used. The film Football Factory and the TV-show Little Britain were closely watched and all slang was noted down and categorized in terms of users and areas of use. The findings were somewhat surprising as the expectation was to find some slang in the chosen material but the amount of slang use exceeded the expectations. Slang seems to be something that people use in many different areas of use, such as, when talking about sex, drugs or other things that might be taboo. It seems that slang is a big part of the language that both men and women use. However, in the material used for this study, young men were the ones who used slang the most.

Within the same vein, (Ningrum, 2009) examines the translation strategy and its impact on the accuracy and acceptability of slang translation in the movie Mean Girls. This study employs descriptive qualitative method. The findings of the study show that there are eight strategies that can be used by the translator in dealing with slang expressions in Mean Girls movie, namely, translation by using slang expression, translation by using common word or phrase of similar meaning, both referential and expressive meaning, translation by using common word or phrase of similar referential meaning but dissimilar expressive meaning, translation by using common word or phrase of similar expressive meaning but dissimilar referential meaning, translation by using common words or phrase of dissimilar both referential and expressive meaning, translation by using loan word or loan word with explanation, translation by omission, and translation by using swearing word from all of the data.

Similarly, Eriksen (2010) examines how slang is transferred from a source text dialogue into a target text subtitle with the American film, I Love You, Man as the data material, with a view to seeing whether the use of slang in the source text is maintained in the target text. The question of the study is 'Does the chosen microstrategies maintain the use of slang in the target text?' Three subquestions are also answered: 'What is the function of slang?', 'Which microstrategies has the subtitler used to subtitle slang in the data material?', and 'What can the chosen microstrategies tell us about the overall macrostrategy?' In this study, it is determined that slang is used with a special goal, i.e., it is used to rebel against standard language and to suggest informal settings.

Within the same context, Barzegar (2012) handles the strategies used in the translation of colloquial expressions in English language films subtitled into Persian. In this study, the colloquial expressions are classified based on the taxonomies presented by McCrimmon (1963) and (Holmes, 1992). The data is gathered from two American comedy films: Midnight Run and Liar which are subtitled into Persian. The colloquial expressions of the films are detected and, with regard to Persian subtitles, the strategies used in translating them, were identified. The analysis of the data indicates that the following strategies are employed by Persian translators: colloquial translation or transfer, deletion, translating into expression with higher degree of formality, paraphrase, condensation or under-translation, semantic equivalent, addition or over translation, mistranslation, and translating into expression with lower degree of formality.

Likewise, Nofalli (2012) carries out a study with the purpose of analyzing slang words, jargon and colloquial expressions found in Transformers movie. The study also aims to identify the translation method found in the Transformers movie. The study found 92 words/utterances of slang, jargon and colloquial expression in the movie subtitle. There are ten examples that were translated using exotics method, three examples using cultural loan, 71 examples using communicative method, one example using idiomatic method, seven examples using adaption method, and there is no data that was translated using the calque method. The findings imply that the translator should know about slang, jargon and colloquial expression, and he/she should also comprehend the method to be followed in translating the source language into the target language as to deliver a good translation.

Ferklova (2014)aims to study several Czech translations for dubbing and subtitles as to see if Czech translators employ the same strategy and if it differs for the two methods. The study presents a detailed analysis of the original dialogues of several films and their corresponding Czech translations for subtitles and dubbing, with a focus on swear words and slang. The study analyses how these elements are used in the original and how they are transferred in the translations, with the aim to uncover possible patterns. The study compares the differences between the subtitles and the dubbing of each film and note whether they met the expectations based on the theoretical research. Finally, the study summaries its findings and discusses what approaches can be observed and whether they can be considered general or isolated, imposed by the method of translation or independent. 


\section{Discussion}

Let us start off by reminding that the running order that will be adopted in this discussion will go as follows: first, the Arabic scene will be given from the film; then, it will be followed by its English subtitling, then a discussion will follow. The brackets are used to signal cases where no translation has been given. Finally, for every example, a suggested subtitling will be offered. Now, let us turn to the film and start the discussion by giving the following examples:

\section{Example 1:}

أبو قيس: لا كنت بعرف

Yes, I knew it

قيس: لأ اليوم بس عرفتو، و عرفتوو إنتبنظّل من الثباك عالصف

No you only learned it today when you were peering through the window

أبو قيس: طيب و إيش صار؟

So what?

راح تقوم القيامة إذا ما كنتش بعرف اشثي عن شط العرب؟!

Is it so important if I knew nothing about Shatt- el- Arab.

Having a quick look at Example (1) above exhibits that Abu Kais asked his son, Kais, about the meaning of (i.e., The Arab Gulf) in order to test out his school education. Kais answered the question correctly and added that he saw him (i.e., he saw his father Abu Kais) while looking at the class. However, Abu Kais tried to show his son that he knew the definition of شط العرب previously. Kais proved to his father that he knew the definition of this concept, as he was looking at the class through the window, and he did not know it before that. Indeed, Abu Kais got angry and his son Kais embarrassed him, because he would not like to appear unknowing or uneducated in front of his little child, who was still attending school. Therefore, Abu Kais decided to belittle or undervalue the importance of this piece of information by using the underlined Arabic colloquial expression in Example (1) below:

طيب و إيش صار ؟ راح تقوم القيامة إذا ما كنتش بعرف اشي عن شط العرب؟!"

So what? Is it so important if I knew nothing about Shatt- el- Arab

The underlined expression"تقوم القيامـة" (lit. summoning for the Resurrection Day) is a problematic Arabic colloquialism that may give rise to subtitling awkwardness. This is so as it refers to a specific society (i.e., the society of Arabs). Arabs and Muslims believe in the Resurrection Day. Accordingly, it is the Day on which the crucial decision for every person whether to go to paradise or to hell will be made. Thus, the colloquialism "تقوم القيامة is used when someone would like to express the idea of something that is crucially important or that is a big deal. Metaphorically, this expression is used to describe any situation or anything that is very important, as if one is equating this to the Resurrection Day.

The subtitling that has been given for this expression is "Is it so important", which seems to have overlooked its cultural aspect of meaning. It is obvious in this film that there is a plenty of colloquial expressions that reflect Arabs' and Muslims' culture so deeply, and so the subtitler should be aware of these important expressions in the film. In this example, the subtitler subtitled the basic meaning of the colloquial expression by following the communicative strategy, in an option that did not seem to have touched upon its Islamic cultural overtone. Therefore, as to give a satisfactory sense, the expression should have been literally subtitled into: Is it The Resurrection Day. This can be a workable literal translation, as The Resurrection Day is a universal concept in most languages, cultures, and faiths.

\section{Example 2:}

سعد: أول اشي لازم توصل لثط العرب، إذا وصلت لهناك بتصير الكويت على رمية حجر

First of all, you must get to Shatt-al-Arab, the Koweit is nearby

In this scene (Example 2 above), Saed describes the road to Kuwait for Abu Kais, as he said that Abu Kais had to arrive at Shatt Al-Arab firstly, and then Kuwait would be so close, or would be "على رمية حجر" (lit. "at a stone's throw"). The colloquial expression " على رمية حجر is an idiomatic-metaphorical colloquial Arabic expression that the subtitler may have experienced difficulty when subtitling it into English, since it has both a metaphorical image and an idiomatic meaning. To elaborate more, the colloquialism " على رمية حجر مئة " has the word , which means throwing, and the word "حجر" which means a stone. Usually, if one throws a stone, mostly, it falls not too far away, however the throwing force is. Therefore, the use of this colloquial expression means in Arabic that something is nearby and not too far away, i.e. very close.

The subtitler, in this example, followed the communicative strategy. So the colloquial expression was subtitled as: nearby. This subtitling conveyed the intended meaning of this colloquialism for TV viewers; yet, neglecting the cultural aspect, (i.e. the metaphorical image of using throwing a stone to indicate the close of something), related to this expression resulted in a subtitling loss for the cultural component of meaning. Thus, the subtitler, in this example, prevented TV viewers from recognizing the SL culture. In fact, it would be more effective and even more impressive if the colloquial expression " "على رمية حجر has been subtitled as: within a stone's throwing distance by adopting the idiomatic strategy. In fact, this is a shared cognitive environment between the two cultures, and so, English does have 
the suggested idiomatic-colloquial expression. Besides, such an idiomatic translation can preserve the metaphor and the beautiful mental image lurking behind it.

\section{Example 3:}

أبو الخيزران: بتعرف؟! أنا خايفلك تفطس البضاعة هون

Abu Al-Khaizaran: Do you know? I am afraid the goods get spoiled here

أسعد:ربك حميد ،هلا الشمس محمولة ولما يجي الظهر بنفوت الختيار لهون وبقعد أنا برا

Asaed: ( ), The sun is still bearable at noon, I bring the old man here and I'll stay outside

Considering Example (3), Abu Al-Khaizaran, the driver who made a deal with Asaed, Marwan and Abu Kais as to take them to Kuwait is talking with Asaed, at the beginning of their trip, about the hot sun and how he is worried about Abu Kais and Marwan because it is scorching hot and because these men were sitting above the tank under the hot sun. However, Asaed said to Abu Al-Khaizaran that the sun heat was bearable. Moreover, Asaed added that at the afternoon, he will change places with the old man (i.e., Abu Kais). Asaed started his talk about how the sun is still bearable by using the colloquial expression "ربك حميد" (lit. "God is benign").

The expression "ربك حميد" (lit."God is benign") is a colloquial Arabic expression that translators and subtitlers alike may face a problem in translating it into English. This expression is used to show that the speaker thanks and praises God for something good. This colloquialism uses one of God's attributes which is, in this case,"الحميد", which means the one who only deserves praising and thanking for the graces and bounties He gave to every human being. As Arabs' religion is Islam, they strongly believe in the attributes of God; Muslims use these attributes in their daily life based on the situation and the context of the situation. So Asaed, here, considered the bearable heat of the sun at the beginning of the day as a grace which requires thanking and praising God for it, which is why he said: "ربك حميد"

In this particular case, the subtitler followed the deletion strategy (i.e., it is the strategy of omitting an expression from the subtitle). Omitting "ربك حميد from the entire subtitle may allude to the subtitler's unawareness or unfamiliarity with the meaning of such a colloquialism. However, by resorting to the communicative strategy in this case, a possible subtitling for the colloquial expression can be thanks God. This suggested subtitling can preserve both the intended and the cultural aspects of the text. In addition, through this subtitling, the TV viewers can obtain a good idea about how the religious discourse is premeating not only formal Arabic but also informal Arabic. Giving the viewer the opportunity to grasp the nitty-gritty of the Arab culture, can also enable them to better understand this specific scene.

\section{Example 4:}

المهرب: يعني إذا ما عجبتك شروطنا انطينا عرض كتاقك وبوشك للجادّة و لا تاخد نفس إلا و إنت عالطريق

The smuggler: that if you don't like it beat it and leave us alone don't stop before you are on the main road.

Having a quick look at Example (4) above, Abu Kais decided to travel to Kuwait and he went to ask an Iraqi smuggler to arrange for a safe trip for him. The smuggler asked Abu Kais to pay 15 Dinars as a wage for the journey. However, Abu Kais had no enough money to pay such a wage (i.e., Abu Kais had only 15 Dinar as a whole), and so, he asked the smuggler to give him a discount as to pay just 10 Dinars so that he can save 5 Dinars. Unfortunately, the smuggler rejected that offer and he insisted on having the 15 Dinars. Moreover, the smuggler told Abu kais that if you would not pay 15 Dinars, you should go away: he fired Abu Kais by using the colloquial expression:

"انطينا عرض كتافك"

(lit. give us the breadth of your shoulders).

The colloquial expression "نطينا عرض كتافك" (lit. give us the breadth of your shoulders) is a problematic one subtitlingwise. Arabs use this colloquial expression as to reject any given unacceptable situations or conditions. In the Arab culture, the best way to show the breadth of one's shoulders is if the person gives you his/her back. Thus, when this expression is used with someone, the speaker is pragmatically making a request from him/her to give his/ her back, i.e., to go away. Arabs consider giving back to someone has a negative meaning as it does not only signals rejecting and refusing what the person has said but it also has the pragmatic meaning of go away or get lost.

The subtitling that has been offered for this expression is : "beat it and leave us alone". Obviously, the subtitler adopted what can be labeled as the semi-communicative strategy. Yet, the semi-communicative choice "beat it and leave us alone" for this expression does not seem to fare so well in this context, as it overlooks its idiomatic meaning. On the other hand, this a choice does not seem to have kept the metaphorical image behind such a colloquialism (i.e. giving someone's shoulders). Indeed, culturally, English employs the idea of giving back. Thus, a better equivalent subtitling for this expression can be suggested along the lines of the full-communicative approach such as: give us your back. This option does seem to approximate the linguistic as well as the cultural differences to great lengths.

\section{Example 5:}

المهرب: عوّد دقولتلك 15 دينار وتوصل للكويت و الخاطر الله أني رجال طامس بالثغل عف عني

15 Dinars and you reach Koweit ( ) I have a lot to do, leave me alone

In this Example (5), Asaed and the Iraqi smuggler negotiate the cost of the trip to Kuwait. However, the smuggler determines that the price of the trip is 15 Dinars. While negotiating this issue, the smuggler wants to show Asaed that he does not care if Asaed accepts to pay the price and travels with him or not; this is the reason why the smuggler used the 
"و الخاطر "والخاطر الله" (lit. "God is the sustenance provider"). The colloquial expression " "اله is an interesting Arabic colloquialism that may well throw up a subtitling challenge, as it refers to Muslims who believe that God is the livelihood-giver. So, people of other faiths may not understand the idiomatic meaning of such a colloquialism.

This expression is used to express that God guarantees the livelihood for people, and He is the only one responsible for providing sustenance for every creature in this life. So, this Islamic view gives people, especially Muslims, some kind of tranquility in their mundane life in particular. Furthermore, when someone uses this expression "الخاطر الخاط that he /she depends totally on God in everything in his /her life and he/she never depends on others. Most of the time, people use this Arabic colloquialism in daily interactions to show that God (i.e., Allah) is the sustenance-provider and the only one who can open up sources of income for all creatures. Thus, Islam asks Muslims to live and to work in dignity and glory without any worry about their future because it is guaranteed by God.

Transltionally speaking, the subtitler gave no subtitling for this expression and he/she decided to drop it out by following the deletion strategy, partly because the subtitler might not have grasped the cultural component of this expression since it is a religious one. As a result, the subtitler preferred to leave it out, thereby causing a considerable subtitling loss. Consequently, the subtitler's decision of dropping out this colloquialism from the screen deprived TV viewers of knowing an important cultural feature of Muslims' belief that God alone is responsible for the livelihood of all creatures. However, the suggested subtitling for this expression is: God is the only sustenance-provider; this subtitling follows the full-communicative strategy which can give its intended meaning and maintain its cultural and religious shad.

\section{Example 6:}

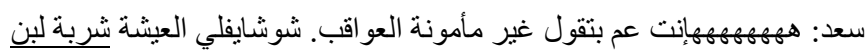

Saed: Ha, ha, ha, Did you say uncertain consequences what. Do you think the act of living is an easy matter

In Example (6) above, Saed travelled to Kuwait in order to work and make money. He worked as a driver there. Since he came back to his birthplace town, he started to describe life in Kuwait and the wealth there. However, at the same time, Abu Kais said that travelling to Kuwait was unsafe and the consequences can be unpredictable. So, Saed replied after laughing: "شوشايفلي العيشة شربة لبن" (lit. "Do you think that life is like drinking a mouthful of yoghurt?").The colloquial expression "شربة لبنة" لشينة (lit. drinking a mouthful of yoghurt) is an interesting Arabic colloquialism that may create a difficult subtitling case. In Arabic, the colloquialism"شربة لبن is used to describe that something is obtainable or affordable. Arabs have many forms of life such as: Bedouins and Peasants. Bedouins and Peasants (i.e., in their daily life) mainly depend on grazing goats, cows, camels, etc. Therefore, milk is always available in Arabs life and is easy to have. The abundance of milk in Arabs life is like the abundance of water. Idiomatically speaking, Arabs use this colloquial expression "شربة لبن for describing that something is so obtainable or accessible.

In this scene of the film, Saed tries to show Abu Kais and others (i.e., other people in the town) that making money is not an easy business, and it needs lots of effort, risks, travels and adventures; then one can live a good life and can entertain the sought dignity. So,Saed used this colloquial expression "شربة لبن in order to summarize and to describe this difficult life and to show, ironically, that making money is not an easy task. The subtitler followed the semicommunicative strategy by giving the subtitling:"the act of living is an easy matter" as an equivalent for the colloquial expression "شربة لبن". By so doing, the subtitler prohibited TV viewers from knowing a popular expression that Arabs use in their daily life. Furthermore, the TV viewers may not understand the scene perfectly because the subtitler made a cultural loss related to Arab's lifestyle. Consequently, to avoid all the previous problems and to give a better subtitling for the expression, it can be best subtitled by following the idiomatic strategy as: Do you think living is a piece of cake! Hence, the option a piece of cake is an established idiomatic expression that can be used formally and informally in English, and so, can be a valid counterpart for the Arabic idiomatic-colloquial expression "شربة لبن .

\section{Example 7:}

سعد: كل ما بيخطر على بالكم بتلاقوه هناك :

Everything you can think of, you will find there

و المعاشات فوق الريح

And salaries are very generous

Within the context of events of the film, Example (7) shows that Saed still describes Kuwait and the different lifestyle there, the high salaries and the abundance of job vacancies. He used the colloquial expression"فوق الريح" (lit. above wind) in describing the high salaries in Kuwait jobs. This colloquialism"فوق الريح" (lit. "above the wind") can be challenging in subtitling. It needs a full understanding in order to convey it accurately in the TL. This expression is used to describe the person who has a lot of money, or who occupies a high-up position, or who enjoys a prime status in society. So, it is used to describe well-off people or those who enjoy a prestigious status, and Arabs use this colloquial expression "فوق الريح" to convey such ideas.

The the subtitler has given the semi-communicative subtitling"very generous" as to convey the semantics of the Arabic idiomatic-colloquialism "فوق الريح". This subtitling does not seem to be quite relevant because there is a very big difference between generosity, entertaining a very special status, or living on high standards. Generosity is not the actual meaning of the expression; rather, it is "enjoying a special financial status", which the subtitler failed to convey, 
probably because he/she may not have realized the cultural aspect of the meaning of this expression, which led him/her to fail to understand its intended meaning. It is obvious that the subtitler tried to give the intended meaning for this expression despite of the lack of his/her understanding for this colloquial expression, thereby unconsciously causing a semantic derailment. This derailment is not without a price: a translational loss. Thus, the colloquialism should have been subtitled after having a full understanding of its intended meaning and its cultural import by following the idiomatic strategy into: And salaries are Sky-rocketing. Though this idiomatic option offers a different mental image; yet, it is gives more or less the same meaning of the Arabic idiomatic-colloquialism "فوق الريح".

\section{Example 8:}

سعد: أب واحد فيكم بيقدر يجمع قرشين بساعة سمّاعة

Saed: Anyone of you can make a little fortune in no time

Considering Example (8), Saed describes the high salaries and the great job vacancies in Kuwait. He also uses the colloquial expression"بساعة سمّاعة" in describing that making money is an easy business over there. The colloquial expression"بساعة سمّاعة" (lit. in a hearing hour) needs a qualified subtitler who understands the strong relation between this expression "بسـاعة سمّاعة" and prayer in Islam. So, it is a problematic colloquial expression for subtitlers who do not realize its idiomatic and cultural meaning (i.e., the religious one).

This expression is idiomatically and culturally used to describe the rapidity and quickness of achieving something in short time and also in a systematic way. It refers to one of the basic beliefs in Islam about making دعاء (i.e. invoking God to give one something he/she badly needs). More specifically, there is a firm Muslim belief that God answers one's دعاء (i.e one's prayer) at any time, but, in some exceptional cases, it may happen that God, in certain times, may answer one's so quickly and in a very short time; this is called in Standard Modern Arabic "ساعة استجابة and in colloquial Arabic ساعة سمّاعة (i.e., prayer's answering moment/time).

However, the subtitler rendered this expression as "in no time" by adopting the semi-communicative strategy. This subtitling has conveyed the intended meaning for the expression, but has not retained its cultural meaning, as the subtitler neglected its religious significance. On the other hand, it seems that the subtitler did not understand and/or did not search for the cultural and/or religious aspect of meaning for such a colloquialism correctly. So, he /she transferred its intended meaning, because the purpose behind using this expression "بساعة سمّاعة in Arabic is to show God's swiftness in responding to, or in answering one's a prayer. Consequently, the subtitling (i.e., "in no time") may not seem quite suitable one, as it ignores the cultural aspects of meaning, which blocks TV viewers from knowing an important cultural feature of Arabic culture and Islamic expressions. Therefore, a presumably full-communicative subtitling for this colloquial expression that may keep its socio-cultural (i.e., religious) overtones is this one: at a divine answering time.

\section{Example 9:}

أبو قيس: شوما حلّك تفهم لسا إنّو ضيعت شجر اتكك وبيتك و إنك ضيعت شبابك وضيعت بلدك كلها؟ عشو معتمد؟

Abu Kais: Are you till unaware that your house and trees are lost? that you have lost your youth and your country? What did you expect?

حكي..حكي..حكي... كله طق حنك

Talks, talks... arguing nonsense

Example (9) above shows that Abu Kais was talking to himself (i.e., he was having a monologue) trying to convince himself to travel to Kuwait in order to work and to be able to make money quickly in light of Saed's description of Kuwait. While he was convincing himself to travel there, he said that "talks, talks...arguing nonsense" to mean the news, the conferences, the world speeches, and all thoughts which have convinced him to stay home struggling with his poverty. Thus, he rejected all these thoughts and all that he heard by saying the colloquial expression"كله طق حنك (i.e. arguing nonsense). This expression "كله طق الحنك" (lit. "clucking of the palate") is a difficult Arabic colloquialism that may present a subtitling challenge. Actually, Arab peasants spend most of their daytime working in their farms , and to kill their time, they talk with each other during this time, and most of their talk is trivial; it is just for entertaining purposes or to kill time. Given that most of their talk is not so important or trivial, they use the colloquial expression "كله طق حناك "

In short, this expression is used to express the idea that a person's talk or speech is trivial, useless, or rubbish. In this particular example, the subtitler has provided "arguing nonsense" as a semi-communicative rendering of the Arabic colloquialism "كله طق حنك as, thereby ignoring its socio-cultural aspects of meaning. Thus, the subtitler does seem to have caused a big subtitling loss in this context. Consequently, the subtitler's decision obliterated the colloquial character of the expression, a subtitling loss that should be made up for. In order to convey a sense that is similar to the original, the idiomatic strategy in this specific example seem to deliver a more satisfactory subtitling, e.g., all of this is hot air. Indeed, this is a conventionalized idiomatic-colloquial expression in English that can meet its Arabic counterpart.

\section{Example 10:}

أبو قبس: ما حلّك تفهم إنو هالحكيما بطعمي خبز؟

Haven't you got it yet that all this is useless? 
In this particular scene (i.e. Example 10 above), again, Abu Kais was talking to himself, i.e., he was having a monologue, trying to convince himself that his situation, i.e., being poor, jobless and homeless, will not be changed. Based on this, Abu Kais described that all news, speeches, conferences and political decisions are useless by using another colloquial expression"مـا بطعي خبز" (lit. "It does not feed bread").This expression "ما بطعي خبز" (lit. it does not feed bread) is an interesting Arabic colloquial expression that may prove hard to subtitle because it is connected with a special cultural meaning. Indeed, this expression is idiomatically used in certain situations to show that something is not important and useless. Moreover, Arabs consider bread as the most important substance for living, and so bread is a symbol of life here. Therefore, bread is normally used in Arabic as to express the idea whether or not something can be a source of income. For instance, if a person has the curiosity to know something, or if s/he wants to know whether or not a business project is useful, s/he would colloquially ask "بطعي خبز؟ which means (lit. Does it feed bread?), and which idiomatically means: can I make a living from this project?

Abu Kais used this colloquial expression " to emphasize the idea that all political speeches and decisions at that time were pointless for him. Thus, he would rather keep living with his poverty if he did not travel to Kuwait and worked as Saed told him. As a result, the strategy of subtitling the intended meaning without paying heed to the idiomatic and/or the cultural aspect can affect some of the subtle messages that the SL film tries to communicate over via such colloquial expressions. In this scene, the subtitler offered the semi-communicative subtitling option:"all this is useless", for the Arabic expression "مـا بطعي خبز" . This does not look to be adequate here, simply because it sacrifices the socio-cultural aspects of meaning. In order to avoid this subtitling loss and in order to give a similar sense, the colloquialism should have been subtitled in a full-communicative sense into something like: it doesn't give you more than scraps. Hence, the word scraps is associated with bits and pieces of bread or anything like this in English, and so, this can be seen as a perfect full-communicative subtitling choice both linguistically and culturally.

\section{Example 11:}

أسعد: يعني لازم أنا أتزوج بنته لأنه هو وأبوي قر أوا الفاتحة لما انولدنا أنا واياها بيوم واحد؟

Asaed: Should I marry his daughter just because her father read Al-Fatiha when we were born the same day?

صاحب أسعد: أكيد هو بعتبر هالإشي قضاء وقدر لا مفر منه

Asaed's friend: No doubt he believes it's destiny

In the scene painted in Example (11)above, Asaed was nervous because when his uncle gave the fifty Dinars to him, the uncle said to Asaed that he wanted him to work and to make money in order to marry his daughter, i.e., Asaed's uncle daughter. However, Asaed complained for his friend about this issue, i.e., the issue of arranged marriage, by raising the question: "Is it obligatory to marry my uncle's daughter, just because my father and my uncle read Al-Fatiha when we were one day old?"At this point in time he used the colloquial expression "قرأوا الفاتحة " (they read Al-Fatiha). Marriage in Arab Islamic regions has many rituals. One of these is reading Al-Fatiha "قر اءة الفاتحـة " (lit. reading the opening Surah of the Holy Qur'an); Muslim usually read this Surah as to mark engagement between a male and female, i.e., once AlFatiha is read, it is understood as a declaration that two people are now engaged to each other.

The subtitler offered a transliterated subtitling for this expression, i.e.,"Read Al-Fatiha". This transliterated subtitling choice does not seem to be a proper one here, as it is made on the assumption that the TL TV viewers are quite knowledgeable on the Arab culture. In fact, this does not hold true. Perhaps, unawareness on the part of the subtitler pushed him/her to keep it as is through adopting the strategy of transliteration. Another detrimental factor that discourages opting for introducing this cultural (i.e. religious) colloquialism is the registral gap between English and Arabic. As it has been already stated, the religious discourse is part of the normal formal and informal modes of expression in Arabic, whereas, it is not in English. In light of all that has been said, the Arabic "Read Al- Fatiha" should have been given a full-communicative subtitling, possibly a choice like this: they got engaged.

\section{Example 12:}

أبو الخيزران: كانت السيارة معطلة

The car broke down

أبو الخيزران: شو اللي عم بضحكن عند هالصبحيا فتاح يا عليم؟

Why everybody is laughing this morning (

Casting a look at Example (12) above reveals that when Abu Al-Khaizaran arrived to the Kuwaiti borders, the second and the last check-point in this journey, he wanted to get his documents signed as quickly as possible. However, three border officers did not recognize that he was in a hurry, and they were laughing when they saw him. He, amazingly, asked them about the reason why they were laughing by saying:

"شو اللي عم بضحكن عند هالصبح بِ فتاح يا عليم؟"

Why everybody is laughing this morning (

The expression "يا فتاح يا عليم" (lit."Oh opener, Oh knowledgeable") is a colloquial expression that may result in subtitling problems, as it only belongs to the Arab culture and, specifically, to the Arab-Muslims' one. Idiomatically speaking, the word " "عليم" means opener or beginner, whereas the word-knowing. Indeed, these are two attributes and/or characteristics of God according to the Qur'an. Normally, these two words are used together with a fixed (irreversible) word order, i.e.,"يا فتّاح يـا عليم". Arabs do use this colloquial idiomatic expression , especially at the 
beginning of the day, or during the first hours of a working day, as a sort of a prayer for God in order to give them anything good and as to start their day with something good. In this scene, Abu Al- Khaizaran used this colloquialism "يا فتاح يـا عليم" after asking the border officers about the reason for laughing, since he entered to sign his documents there. He felt that there was something strange and that they changed the way they were dealing with him, which is why he used this expression, indicating to the beginning of the day (i.e., because the event happened in the morning), and also to express the idea that it is only God who knows the reasons why they changed the way they dealt with him.

This colloquial expression, i.e., "يا فتاح يـا عليم" was not expressed in the film's subtitling at all, as the subtitler followed the deletion strategy. It can be noticed that the subtitler neglected transferring the intended meaning and the cultural characteristics of colloquialisms which carry very important implied meanings. The implied meaning in this expression is that the event was in the morning. Moreover, the intended meaning is that something caused a change in the way border officers deal with Abu Al-Khaizaran, and this would potentially confuse the T.V. viewers over why Abu Al-Khaizaran got angry to finish his documents very quickly on the Kuwaiti borders. Therefore, the fullcommunicative strategy may yield better subtitling results for this colloquialism, such as: what's wrong with you? Or what's up? The reason why a literal translation is counterproductive for this particular colloquialism is the fact that unlike Arabic, the religious register is not part of neither the formal nor the informal style of English. This can really shock the target language TV viewers.

\section{Conclusion}

Analysis isolates three major problems relevant to subtitling Arabic colloquial expressions into English: (1) some colloquialisms, reflecting religious overtones, have been missubtitled, (2) some colloquialisms have been totally dropped out from subtitling, (3) and in subtitling certain examples, a considerable loss of the cultural aspect of meaning has occurred. Finally, to resolve such recalcitrant problems and difficulties, the study, in its concluding part, suggests some other practical subtitling mechanisms, other than the ones that have been adopted by the movie's subtitler.

The present analysis shows that three subtitling strategies have been adopted by the subtitler. These include the deletion strategy: the subtitler, in some specific cases, resorted to the strategy of deletion. It has been found that some colloquial expressions were overlooked in subtitling, i.e., no subtitlings have been given to some colloquialisms that were detected and analyzed in this study. This conclusion can be accounted for by the fact that some Arabic colloquial expressions are normally much more difficult to subtitling than others, a fact which complicates the job of the subtitler. Such cases may be justifiable in some contexts, but the subtitler is supposed to do his/her best to subtitling everything, especially when it comes to subtitling films. In fact, deleting some parts of the film may cause problems, loss of meaning, change in meaning, and misunderstanding. The subtitler's task is not easy as he/she deals with the spoken language, but he/she should try not to leave any part with no subtitling, which requires him/her to use different subtitling strategies and find solutions to any problems that may face him/her. Second, the semi-communicative strategy: the subtitler employed a semi-communicative subtitling technique, focusing on a certain aspect of the message without paying attention to some other important ones too. Third, the transliteration subtitling strategy: the subtitler used transliteration in subtitling one colloquial expression. In subtitling films, it seems that transliteration is not an effective strategy. This strategy might be easily and effectively used in written texts as the translator can add footnotes, but in subtitling this option is usually hard to rely on, as the TV viewer cannot leave the programme they watch as to search for the meaning of any given transliterated form showing on the screen. So, transliteration may not be a reliable option for the subtitler.

Three more subtitling strategies can be suggested as to resolve the problems that have been discussed in this study. These include firstly what can be termed the full-communicative strategy: this strategy involves offering a fullcommunicative subtitling of some colloquial expressions in question, i.e., this strategy depends heavily on the context of the colloquial expression in order to study the exact scene of the film as to understand the exact communicative meaning of it. This strategy has been used in this study as to deal with the semantic loss problem, and the cultural loss problem. Secondly, the idiomatic strategy (i.e. idiomatic colloquial-for-idiomatic colloquial): this strategy includes offering an idiomatic-colloquial subtitling of certain colloquial expressions discussed in this study. This strategy has been used in this study as to provide for the established SL idiomatic-colloquialism an equivalent established TL idiomatic-colloquialism. Thirdly, the literal strategy proved to be an expedient approach in certain specific contexts; this has only been restricted to cases of shared cognitive environment between the two languages and cultures; otherwise, literal translation can be quite destructive.

\section{References}

Al-Azzam, B., \& Al-Kharabsheh, A. (2011). Jordanian Folkloric Songs in Translation: Mousa's Song They Have Passed by Without a Company as a Case Study. Meta: Journal des traducteurs/Meta: Translators' Journal, 56(3), 557578 .

Barzegar, H. (2012). Translation of Colloquial Expressions in English-into-Persian Subtitled Films. Retrieved from www.translationindustry.ir website: http://www.translationindustry.ir/Uploads/Pdf/Translation\%20of\%20Colloquial\%20Expressions\%20in\%20English.pdf Cabrera, G. M., \& Bartolomé, A. I. H. (2005). New trends in audiovisual translation: The latest challenging modes. Miscelánea: a journal of English and American Studies(31), 89-104.

Chang, Y. (2012). A Tentative Analysis of English Film Translation Characteristics and Principles. Theory and Practice in Language Studies, 2(1), 71. 
Chiaro, D. (2009). Issues in audiovisual translation. The Routledge companion to translation studies, 141-165.

Chiaro, D., Heiss, C., \& Bucaria, C. (2008). Between text and image: updating research in screen translation (Vol. 78): John Benjamins Publishing.

Condinho Bravo, M. d. C. (2008). Putting the reader in the picture. Screen translation and foreign-language learning. (Unpublished PhD Dissertation), Universitat Rovira i Virgili, Spain.

d'Ydewalle, G. (2002). Foreign-language acquisition by watching subtitled television programs. Journal of Foreign Language Education and Research, 12, 59-77.

Delabastita, D. (1989). Translation and mass-communication: film and TV translation as evidence of cultural dynamics. Babel, 35(4), 193-218.

Díaz-Cintas , J. (2003). Audiovisual translation in the third millennium. Translation today: Trends and perspectives, 192-204.

Díaz-Cintas, J. (2008). Audiovisual translation comes of age. Delia Chiaro, Christine Heiss \& Chiara Bucaria. Between Text and Image: Updating Research in Screen Translation. Amsterdam: John Benjamins, 1-9.

Díaz-Cintas, J., \& Anderman, G. (2008). Audiovisual translation: Language transfer on screen: Springer.

Díaz-Cintas, J., \& Remael, A. (2014). Audiovisual Translation, Subtitling: Routledge.

Eftekhari, N. (2008). A comparative study of the translation of colloquialism in English subtitles of the Iranian film" The Wind Will Carry Us.

Eriksen, M. H. (2010). Translating the use of slang. Institut for Sprog og Erhvervskommunikation, Aarhus School of Business, Aarhus University.

Fawcett, P. (2003). The manipulation of language and culture in film translation. 2003, 145-163.

Ferklova, S. (2014). Subtitles vs. Dubbing: Approaches to Translation of Swear Words and Slang in Film. Masaryk University, Faculty of Arts.

Fodor, I. (1976). Film dubbing: phonetic, semiotic, esthetic and psychological aspects. Hamburg: Helmut Buske.

Gambier, Y., \& Gottlieb, H. (2001). (Multi) media translation: concepts, practices, and research (Vol. 34): John Benjamins Publishing.

Gottlieb, H. (1997). Subtitles, Translation and Idioms, 2 vol. Copenhague. Center for Translation Studies and Lexicography, Department of English, University of Copenhaguen.

Gottlieb, H. (2008). Screen translation Understanding translation: Systime Academic.

Hamaida, L. (2007). Subtitling slang and dialect. Paper presented at the MuTra 2007-Audiovisual Translation Scenarios: Conference Proceedings.

Holmes, J. (1992). An introduction to sociolinguistics: London: Longman.

Ivarsson, J., \& Carroll, M. (1998). Subtitling: TransEdit.

Luyken, G.-M., \& Herbst, T. (1991). Overcoming language barriers in television: Dubbing and subtitling for the European audience (Vol. 13): European Institute for the Media.

Mason, I. (1989). Speaker meaning and reader meaning: preserving coherence in screen translating. Babel. The Cultural and Linguistic Barriers between Nations, 13-24.

McCrimmon, J. (1963). Writing with Purpose (3-ed). New York/Houghton: Boston: Houghton Mifflin Company.

Ningrum, N. A. R. (2009). An analysis of slang expressions translation in "mean girls” movie. (Unpublished PhD Thesis), Sebelas Maret University. Retrieved from https://core.ac.uk/download/pdf/12347900.pdf

Nofalli, T. S. (2012). Slangism and Colloquialism Expression in Subtitle Text of" Transformers" Movie. Skripsi, Fakultas Ilmu Budaya.

O'connell, E. (2007). Screen translation. A companion to translation studies, 120-133.

Orero, P. (2004). Topics in audiovisual translation (Vol. 56): John Benjamins Publishing.

Pedersen, T. (2009). The Use of Slang in British English: A Study of the Slang used in Football Factory and Little Britain. (Independent Thesis Basic Level (Degree of Bachelor)), University of Kalmar, Unpublished B.A. Thesis. Retrieved from http://lnu.diva-portal.org/smash/record.jsf?pid=diva2\%3A234593\&dswid=-9876

Pérez-González, L. (2014). Audiovisual translation: Theories, methods and issues: Routledge.

Popowich, F., Turcato, D., Laurens, O., McFetridge, P., Nicholson, J. D., McGivern, P., . . . MacDonald, S. (1997). A lexicalist approach to the translation of colloquial text. arXiv preprint cmp-lg/9706024.

Romero-Fresco, P. (2011). Subtitling through speech recognition: Respeaking: St. Jerome Pub.

Snell-Hornby, M. (1988/1995). Translation studies: An integrated approach: John Benjamins Publishing.

Taivalkoski-Shilov, K. (2008). Subtitling 8 Mile in three languages: Translation problems and translator licence. Target. International Journal of Translation Studies, 20(2), 249-274.

Thawabteh, M. A. (2011). Linguistic, cultural and technical problems in English-Arabic subtitling. , SKASE Journal of Translation and Interpretation, 5(1).

Varela, F. C. (2002). Models of research in audiovisual translation. Babel, 48(1), 1-13. 